\title{
A Nuclear Submarine in the South Atlantic: The Framing of Threats and Deterrence
}

\author{
Mônica Herz* \\ Layla Dawood $^{* *}$ \\ Victor Coutinho Lage ${ }^{* \star *}$
}

\begin{abstract}
In this article, we analyse one aspect of Brazilian nuclear policy during the tenure of the Workers Party (2003-2016): the development of a nuclear-propelled submarine. We propose that the project of building a nuclear-propelled submarine has become possible partly because of the mobilisation of a set of arguments for the construction of the South Atlantic as a strategic area, framed in terms of security and development. On the other hand, we contend that the need for a nuclear-propelled submarine is framed through the mobilisation of a specific notion of deterrence. In other words, we claim that the notions of 'strategic area', 'general deterrence', 'conventional deterrence', and 'deterrence by denial' can help us analyse the fundamental aspects involved in the framing of the South Atlantic as a security concern, justifying the nuclear-propelled submarine project.
\end{abstract}

Keywords: Nuclear Submarine; Threats; Deterrence; South Atlantic; Brazilian Nuclear Policy.

\section{Introduction}

In this article, we analyse one aspect of Brazilian nuclear policy during the tenure of the Workers Party (2003-2016): the development of a nuclear-propelled submarine. There are three main sets of arguments put forward by the Brazilian ruling elites for the nuclearpropelled submarine project: first, the concern with the autonomy of the country's foreign policy and even the prospects of becoming a major power and joining the UN Security Council; second, the association between development and control of nuclear technology (Herz, Dawood and Lage, forthcoming); and finally, the arguments for the construction and consolidation of the South Atlantic as a strategic area. In this text, we focus on the third set of arguments. ${ }^{1}$

\footnotetext{
* Pontifical University of Rio de Janeiro (PUC-Rio), Rio de Janeiro-RJ, Brazil; m.herz.rio@gmail.com.

** State University of Rio de Janeiro (UERJ), Rio de Janeiro-RJ, Brazil; layladawood@hotmail.com.

*** Pontifical University of Rio de Janeiro (PUC-Rio) and Getulio Vargas Foundation (FGV-Rio), Rio de Janeiro-RJ, Brazil; victorcoutinholage@yahoo.com.br.
} 
Our contention is twofold. On the one hand, we propose that the project of building a nuclear-propelled submarine has become possible partly because of the mobilisation of a set of arguments for the construction of the South Atlantic as a strategic area, framed in terms of security and development. On the other hand, we contend that the need for a nuclear-propelled submarine is framed through the mobilisation of a specific notion of deterrence. In other words, we claim that the notions of 'strategic area', 'general deterrence', and 'conventional deterrence' can help us analyse the fundamental aspects involved in the framing of the South Atlantic as a security concern, justifying the nuclear-propelled submarine project. We will unpack both arguments in the second and third sections below.

This is a crucial theme, as it has generated concern internationally (see Diehl and Fujii 2008; Taylor 2009) and it has mobilised an important amount of resources nationally. Currently only the five permanent members of the United Nations Security Council and India dominate such technology. Thus, Brazil would become the first non-nuclear state to develop a nuclear-propelled submarine. Moreover, the project generated questions and concerns regarding the Non-Proliferation Regime and the potential for the production of weapons-grade material. In particular, international suspicions have arisen due to the type of fuel Brazil might use in its nuclear submarine. ${ }^{2}$ According to article 14 of the Treaty on the Non-Proliferation of Nuclear Weapons (NPT), nuclear fuel could be exempt from safeguards. Even though non-explosive military use of nuclear technology is within the scope of the NPT, specialists have questioned whether Brazil would provide guarantees that the nuclear material used by the submarine will not be diverted to other military uses such as the construction of a nuclear weapon. The Brazilian government has put forward three reasons why international concern are not grounded: (1) Brazil will not invoke article 14; (2) the Quadripartite Agreement (Article 13) establishes that special provisions will have to be negotiated in order to apply safeguards to this military capability; and (3) the plans are not for use of highly enriched uranium (HEU). More specifically, Brazilian authorities have stated that uranium enrichment would be at $19.9 \%{ }^{3}$

Crucially, we should also mention that the construction of the arguments for investing in the nuclear submarine has been made mainly by the Brazilian Navy, and the level of support for this project within the Navy has become extremely high, as Admiral Armando Vidigal lets us know: 'Our ultimate goal is the nuclear submarine ... I say that with unease because the Navy has turned the nuclear submarine into a symbol, and whomever is against this symbol will encounter serious opposition in the Navy' (cited in Martins Filho 2011: 294-5).

We thus present in this article an interpretation of the Brazilian nuclear submarine project based mainly on an analysis of the security and development arguments put forward by the Brazilian elites directly involved in the project. We turn to the definition of threat and the security practices that have allowed for the generation of this project, asking how it was possible to mobilise the meanings in question not only through language, but also through security techniques involving methods, procedures, and plans (Huysmans 2006: 11). This is crucial, we propose, as no policy can be regarded as natural and must be looked into as political choices. We would like to start by stressing, in line with Jef Huysmans' discussion of the politics of insecurity, that defining what the threat is and what is 
being threatened is a political process, through which choices are constantly being made. The definition of threat and the priority it merits are always in dispute. Here we want to analyse the manner in which the Brazilian ruling elite ${ }^{4}$ has justified the need for investment in nuclear technology through the framing of domains of insecurity regarding the South Atlantic strategic area. The South Atlantic has been modulated discursively and institutionally in terms of a security rationality. This rationality renders events intelligible as security events (Huysmans 2006: 16). Routines and administrative instruments (Bigo 2002) developed by the Brazilian state, but more particularly by the Navy, are part of the framing process we are analysing here. We contend that the language and practice of security 'smuggles in' (Huysmans 2006: 25) an inimical construction of inter-state relations even when there is no clear definition of the enemy.

The ideas that shape the policy will be analysed in terms of frames, in line with Irving Goffman's (1974) work, allowing us to understand how arguments conceptualise and categorise empiric experiences. Framing thus makes possible the different forms of justification of political action. We will look into the arguments put forward by the ruling elite, the embeddedness of these arguments in aspects of Brazilian elite culture, and the process of transformation of arguments into public policies. As Crawford puts it, 'political argument is public reason' (Crawford 2002: 12). We look into the arguments given by social actors and how they are translated into action. In particular, we are interested in practical arguments which refer to how to act in the social world. These arguments establish cause and effect relations. As different actors make public arguments, they frame or represent situations.

This text is divided into three main parts. We begin by providing an overview of the nuclear submarine project in its current stage. After that, the second section moves towards the discussion of the framing that makes this project possible in terms of an area under threat. Then, the third section deals with the security logic of deterrence related to the framing of this strategic area.

\section{The Brazilian nuclear submarine}

The project of constructing a nuclear submarine has been present in Brazilian politics since the 1970s and should be understood within the wider context of Brazilian nuclear policy, which dates back to the 1950s. In the end of the 1970s, a programme to develop nuclear technology was set up under the responsibility of the Brazilian Navy with two main goals: mastering the nuclear fuel cycle and building a nuclear reactor which would later be used for the propulsion of a Brazilian nuclear submarine (Moura Neto 2013; Viveiros and Cespes 2013). The Navy achieved isotopic enrichment in 1982, and by 1985, it was able to produce cascade enrichment (Sá 2015). But such projects stalled in the 1990s as Brazil moved toward acceding to the nonproliferation regime under governments that were not supportive of the project. In 1992, for example, even the head of the Navy appointed by President Itamar Franco, Admiral Ivan da Silveira Serpa, did not support the idea (Sá 2015). Investment in the project resumed after the Workers Party came to power with the election of Luis Inácio Lula da Silva and the Roussef administration continued to further develop it (Martins Filho 2011; 2012). 
In a significant move, in 2005, Admiral Othon Luiz Pinheiro da Silva was appointed head of Eletronuclear. This appointment was a clear indicator of the new relevance of the Brazilian nuclear projects, since Admiral Othon is considered one of the fathers of the Brazilian nuclear programme and was tasked in the 1980s to build a nuclear reactor. Moreover, he established and led Brazil's centrifuge uranium enrichment programme, being the person responsible for the nuclear fuel development cycle programme and the nuclear powering for submarines initiative from 1979 to 1994 . Another important development took place in 2007, when President Lula visited the Aramar facilities and announced that he would authorise one billion Brazilian reais (BRL) to revitalise the programme (Kassenova 2014). ${ }^{5}$

The Brazilian Nuclear Submarine Project (PROSUB), which is headed by the Navy, is currently based at the Navy Aramar Experimental Center, where work is underway to develop a prototype of a nuclear-powered submarine and where uranium enrichment at 19.9\% takes place (Martins Filho 2011; 2012). This is a long-term project, which aims to complete the construction of the first nuclear-propelled submarine in the 2020s. The construction is under the responsibility of Itaguaí Naval Construction (Itaguaí Construções Navais), a consortium of Odebrecht (a Brazilian company) and the French company Direction des Construtions et Navales Services (DCNS) (Kassenova 2014).

Brazil's future nuclear-powered submarine capability is considered by the Navy as having a crucial role to play in defending the country's territory and resources, particularly in offshore waters, as we discuss below. It will be armed with conventional torpedoes, thus increasing Brazil's conventional deterrent capability, in accordance with the Navy's framing.

For the concretisation of the nuclear submarine project, it was necessary to first develop or acquire from other countries the technology to design and build submarines. The Brazilian Navy had acquired the technology to build submarines from Germany in the late 1980s, but still did not have the ability to develop submarine-related projects. Between developing such technology and acquiring it from other countries, Brazil opted for international co-operation for the acquisition of this capacity (Moura Neto 2013), and in 2008, a partnership was announced between Brazil and France for the construction of submarines (Viveiros and Cespes 2013; Moura Neto 2013). In line with this investment in technological development, after 2010, Brazilian engineers studied in the city of Lorient, where the School for Submarine Projects was established. It is noteworthy that France was the chosen partner since the country accepted the Brazilian conditions of transferring technology to design submarines and the fact that the country was already exporting conventional Scorpène submarines to Chile, Malaysia, and India (Correa 2012).

In 2012, the opening ceremony of PROSUB took place: during this project, four conventional submarines and one nuclear submarine are planned to be built ${ }^{6}$. With the exception of the first, the other submarines are to be built in Brazil and the expectation is that the domestic content of the submarines will be high. France is providing assistance for the development of the non-nuclear components. ${ }^{7}$ Under the same agreement, Brazil would buy 50 military helicopters. The total value of the contracts signed was reported at $\$ 12$ billion. 
It is important to understand that this project is part of a wider move to modernise the Brazilian armed forces. According to the official website of the Ministry of Defence, during the administrations of presidents Lula and Dilma, the absolute defence spending increased from BRL 25.8 billion in 2003 to BRL 76.9 billion in 2014. Moreover, in 2005, an official work group was established by presidential decree to plan the modernisation of the Brazilian Navy's capabilities. The group was composed of members of several ministries, including Defence, Economy, and Planning, Budget and Management. In August 2006, the group finalised a report which was delivered to the Defence Ministry. It divided the modernisation process into two phases: the first lasting until 2014 and second lasting until 2025. The stated goal of the first modernisation stage was to build, modernise, and acquire naval means such as submarines and torpedoes, patrol ships, escort ships, river escort ships and helicopters. ${ }^{8}$

In spite of the increase in absolute numbers, there was a slight decrease in terms of the percentage of the GDP devoted to defence (from 1.46\% in 2003 to $1.39 \%$ in 2014). Therefore, it is important not to overestimate eventual increases in the defence budget noting that, historically, a great proportion of Brazilian defence spending goes to the payment of personnel. ${ }^{9}$ For instance, in $2014,72 \%$ of the total defence budget was spent on personnel, $15 \%$ on operational costs, and $11 \%$ on investments. In other words, the absolute increase in defence spending did not necessarily translate into real improvement of capabilities or modernisation. The Naval forces budget more than doubled between 2005 and 2015: from BRL 7.2 billion to BRL 16.2 billion. Nevertheless, from the total Brazilian Navy's budget, BRL 14.5 billion was spent on personnel. This is to say that most of the Navy's budget increase was not due to new investments or the acquisition of new naval capabilities.

Therefore, the modernisation plans have not yet led to the significant modernisation of Brazilian Naval capabilities. Brazil has one aircraft carrier (the São Paulo, which was built by France in the 1960s and acquired by Brazil in 2000), but it is not operational at the moment. The naval authorities plan to modernise the carrier and to extend its operational life up to 2025. In terms of escort ships, Brazil has nine frigates: six frigates (Niteroi class) were built by the end of the 1970s and revitalised during the period from 1996 to 2006 and three (Greenhalgh class) were built in the 1980s and bought by Brazil in the 1990s. The Greenhalgh class frigates will soon go through renovation to expand their operational life so as to last 15 years more. In terms of corvettes, four Inhaúma class corvettes were renovated in 2008 and will also have their operational life expanded for 15 years. Lastly, the Barroso corvette was recently incorporated in the fleet. Since most of Brazil's frigates and corvettes will stop being operational by 2025 , the arsenal will have to be replaced, but the process to replace old ships has moved slowly. ${ }^{10}$

Without a doubt, the current major priority of the Brazilian Navy has been the acquisition of a nuclear submarine force. For the development and construction of the first Brazilian nuclear powered submarine, a public enterprise was founded: the Amazônia Azul Tecnologia de Defesa S.A. (Amazul). The Amazul budget is independent from the Naval forces budget. From 2013 to 2015, the public firm received the total of BRL 893.6 million. ${ }^{11}$ The first estimate was that the first Brazilian nuclear submarine would be ready by 2025 , 
but that has been challenged by the Brazilian media in view of the current political and economic situation of the country (Prazeres 2015).

After presenting an overview of the current situation of the Brazilian naval forces and, more specifically, of the Brazilian project to develop a nuclear-propelled submarine, we now move to the discussion of the main set of arguments put forward by the ruling elites in justifying the new investments. We focus on the role performed by the South Atlantic strategic area in the political process analysed. ${ }^{12}$

\section{Framing the South Atlantic as a strategic area}

The argument put forward by Brazilian elites regarding the characterisation of the South Atlantic Ocean as an area of strategic interest to Brazil is related to the debate on regionbuilding. The literature on region-building has evolved during the last twenty years in line with the constructivist perspective on the role of discourse and the processes of identitybuilding (see Neumann 1994; 1999; Acharya 2007; 2011; Herz 2014). Region-building involves the construction of arguments on the specificity of a certain geographic area and the practice of co-operation and co-ordination with countries that may be involved in the project. The literature refers to a change in relations between countries of a certain region, the institutionalisation of regionalism often through international regional organisations, and the role played by region-builders and the constitution of collective identities.

Clearly, the Brazilian ruling elites frame the South Atlantic as an area with specific characteristics which is under threat and which can agglutinate interest of a number of countries. In view of that, Abdenur and Souza Neto $(2013 ; 2014)$ argue that a new regionbuilding process in the South Atlantic has been launched. According to the scholars mentioned, factors that allow for the process to take place are: the discovery of large offshore oil reserves, including in the pre-salt layers of Brazil's legal waters; the concern regarding the presence of great powers within the South Atlantic; worries about the increase of piracy and other illicit activities; and control of several South Atlantic islands by the United Kingdom, among them the Malvinas/Falklands. The authors analyse how the Ministry of Defence, the Navy, and the Ministry of Foreign Affairs have articulated a discourse on the region. Indeed, in 2007, the state oil company Petrobras announced the discovery of large reserves of oil in the pre-salt layers on and beyond Brazil's continental shelf and this generated further interest and concern regarding the South Atlantic. These authors and others have highlighted a growing perception of threat in relation to the North Atlantic Treaty Organization (NATO) (Luis 2012; Abdenur and Souza Neto 2013). The threat perceptions in the South Atlantic arise mainly from the presence of external powers in the region. Former Minister of Defence of Brazil, Nelson Jobim, has focused on partnership initiatives between members of NATO and countries of the South Atlantic. He has shown, on several occasions, concern with the new strategic concept of NATO approved in 2010 (see NATO 2010). The document proposes the approximation of NATO to countries which do not belong to the geographical boundary of the organisation by conducting military exercises with them, among other forms of co-operation. The international presence, notably by the UK, which holds title to several islands in the South Atlantic, among which are the 
Falkland Islands/Malvinas, can mean potential sources of tension, as already occurred during the 1982 War. In addition, the announcement by the United States to revive the Fourth Fleet (originally formed in 1942 and disbanded in 1950), responsible for the US naval presence in the South Atlantic, increased Brazil's concerns with the surveillance and defence of the sea lines of communication and the resources of the Brazilian Continental Shelf (Abdenur and Souza Neto 2013: 171-2). In a different article, they point out that the presence of countries such as China, Russia, India, and NATO countries were a concern for both the Lula and the Roussef administrations (Abdenur and Souza Neto 2014).

Indeed, the military establishment, more specifically the Navy, has produced specialised knowledge in the field of strategic analysis and defence studies and ocean geology that are the basis for the arguments put forward. As Huysmans notes, 'Security framing constitutes domains of political interaction by distributing and administering fear and trust' (Huysmans 2006: 51). The construction of the South Atlantic area involves building trust on the inter-state level and a movement to distance the states that form the South Atlantic area from the rest of the world, primarily the countries of the North Atlantic. A difference between relations of trust between these countries and uncertainty regarding other actors present or potentially present in the South Atlantic is expressed by discursive and institutional practices. The construction of knowledge about the South Atlantic is a crucial part of this process.

Relations of power allow this project to move forward and are reproduced in the process. The Brazilian government has asserted its role as a powerful actor influencing the production of rules that constitute the relations between the different countries involved in the South Atlantic. The Brazilian Navy and specialists have been able to produce the knowledge about the area that is framing the debate on rights and on threats. In the process, the Brazilian government was able to focus on the ties that link the coastal countries of the South Atlantic.

However, in spite of the contributions those discussions on the construction of a 'South Atlantic region' provide, we claim that the argument on region-building should not be taken without some qualifications. The Navy and other authorities often refer to the South Atlantic as a region, but this does not necessarily mean that a region has effectively been built in the area. In turn, we argue that the set of arguments put forward by Brazilian ruling elites claiming the South Atlantic to be a region allows for the investments in the nuclear propelled submarine. This is not the same as saying that we agree with the statement that a region has been built. The terms 'regionalism', 'regionalisation', or 'region' (see Herz 2014) have become associated with regional projects involving a profound change in relations between countries that are generally geographically continuous and at times includes the construction of a new collective identity. Regarding the South Atlantic, what we clearly observe is an attempt to increase security over a vast oceanic area, considered to be 'strategic', as well as attempts to mobilise the coastal countries for further co-operation. With that in mind, when referring to what has been constructed regarding South Atlantic Ocean, we opt for using the notion of 'area', instead of 'region'.

In the South Atlantic area, we observe a political project based on a group of arguments and practices which aim at defining threats and at producing fear. During the 
tenure of the Workers Party, the South Atlantic was framed to be under threat and was moved up the priority list of policymakers, particularly vis-à-vis the Amazon region, and the legitimate methods of governing the area were changed in the process. The national security discourse establishes that there is a threat to the control of the resources that are considered crucial. The control of the South Atlantic is framed as precarious, linking security and insecurity as two sides of the security framing coin.

In fact, the South Atlantic had been treated as a relevant area by sectors of the Brazilian elite since the 1960s, and interest in legal definitions of maritime rights was present even before that. In 1934, 12 miles was defined as a fishery zone according to Brazilian law. In 1969, the government established a 12-mile territorial waters limit and, in 1970, a 200mile limit. But, in 1994, in line with the newly elected government's tendency to adhere to international norms, the definition of 12-mile territorial waters limit was accepted, apart from a 200-mile exclusive economic zone, in line with the United Nations Convention on the Law of the Sea.

The Ministry of Foreign Affairs, the Brazilian Navy, and Petrobras have been involved for many years in a project to extend the rights over the continental platform, as Alexandre Pereira da Silva points out (Silva 2013). The Continental platform has been under scrutiny since the 1970s, when there was a belief in the economic potential of the area (Castro 1989: 20). The exploration of the platform began in 1968, and oil was being drilled in 1977. The Plan of Research of the Brazilian Continental Platform (created by the decree 98145 of December 1989) was created under the leadership of the Hydrographic and Navigation Board of the Navy, with the support of Petrobras (Vidigal 2006: 51). Geophysical and barometric data were analysed for 18 years in order to produce a description of the Brazilian Continental Shelf and was presented for the consideration of the UN Commission on the Limits of Continental Platforms.

In 2004, Brazil submitted to the Commission a project claiming the extension of its continental platform (900 000 square kilometres, approximately 347492 square miles). In 2007, the Commission ruled that the Brazilian plea would be accepted with a cut of $20 \%$ of the area requested (that is, 190000 square kilometres, approximately 73360 square miles). This decision reinstated the relevance of the nuclear submarine project, since it is argued that this capability would help to protect the Brazilian continental platform.

This experience allows Brazil to support research on the subject for a number of other countries such as Namibia, Angola, Mozambique, Guyana, and Uruguay, linking the logic of South-South co-operation and interest in oil exploration. Among the consequences of the extensive research which involved the navy and Petrobras, the navy's website mentions: 'Unequivocal demonstration for the international scientific community that Brazil is in fact capable of an effective presence in the South Atlantic, in the context of oceanographic enterprises.' ${ }^{\text {13 }}$

Brazil sought to secure its interests in the South Atlantic area through international co-operation in different contexts. During the Cold War, in line with the definition of the non-proliferation regime as it precluded the presence of nuclear powers in this part of the southern hemisphere, the South Atlantic Peace and Cooperation Zone (ZOPACAS) was launched and widely supported. During the period in focus here, the emphasis has been 
on South-South cooperation. In fact the two logics became intertwined during the last decade, as maintaining the South Atlantic as an area where South-South cooperation can take place and attempting to preclude the presence of nuclear powers are part of the framing we are discussing here.

In the mid-1980s, Brazil supported the creation of ZOPACAS. In 1986, after consulting with African and Latin American countries, the Brazilian government presented a proposal to the UN General Assembly to make the South Atlantic a non-nuclear zone, and the following year, 124 countries approved a UN General Assembly Resolution declaring the South Atlantic a zone of peace and cooperation which sought to keep the region free of Cold War proxy wars as well as nuclear weapons. ${ }^{14}$ ZOPACAS is formed by 24 countries and aims to maintain the region as a zone free of conflicts and of weapons of mass destruction. In 1994, a declaration on the denuclearisation of the South Atlantic was issued. ${ }^{15}$ The revitalisation of ZOPACAS occurred during the Lula administration, starting with a 2006 meeting held in Luanda.

Abdenur and Souza Neto (2013) also call our attention to the Brazilian interest in fostering military cooperation, involving training and equipment supply with the coastal African countries such as South Africa, Namibia, Angola, São Tomé and Principe, and Cameroon (Abdenur and Souza Neto 2013: 13). Brazil has been strengthening its military co-operation initiatives in Africa, especially with African countries located on the South Atlantic rim. Relations with South Africa are particularly important. Brazil and South Africa co-operate on various fronts: the countries have military exchange programmes, their armed forces carry out joint military exercises, and, for the last decade, the countries have been co-operatively developing military capabilities. The main bilateral initiative to develop military capabilities is the A-Darter missile project, an air-to-air missile projected to hit targets within 12 kilometres. The development of the missile is at an advanced state, and the authorities are currently planning its industrialisation. In Brazil, the Air Force is responsible for the management of the project, which also involves the private sector, namely enterprises such as Avibrás, Mectron, and Opto. In South Africa, a state enterprise named Denel is in charge of the project. According to the Brazilian Ministry of Defence, the A-Darter project led to transference of technology and integration among the defence industries of the two countries. ${ }^{16}$

Namibia, on the other hand, was the first African country to sign a defence agreement with Brazil. After Namibia, came Cape Verde (1994), South Africa (2003), Guinea-Bissau (2006), Mozambique (2009), Nigeria (2010), Senegal (2010), Angola (2010), and Equatorial Guinea (2010 and 2013). In 2012, joint exercises were carried out with the navies of Benin, Cape Verde, Nigeria, and São Tomé and Príncipe. In 2013, additional exercises were pursued with Angola, Mauritanea, Namibia, and Senegal. In 2014, Brazil established a naval mission in Cape Verde. Brazil offers military training to African officers: between 2003 and 2013, the Naval School and the Naval War School received around 2000 officials from Namibia. Since 2009, there has been a joint co-operation structure between the Brazilian Cooperation Agency (Agência Brasileira de Cooperação, ABC) and the Ministry of Defence, directed to the training of African military (Thompson and Muggah 2015). 
In line with the renewed framing of the South Atlantic as an area of strategic interest for Brazil, Admiral Roberto Guimarães Carvalho coined the expression 'Blue Amazon' By doing so, he highlighted the need for the protection of this area, in line with the relevance attributed to the Amazon region, denoting that the South Atlantic area could bring benefits to Brazil of the same magnitude as the Amazon forest (Correa 2010: 175).

The Brazilian ruling elites' concern with the protection of the South Atlantic was confirmed by the 2005 National Defence Policy and by the 2008 Defence Strategy. According to the former, Brazilian interests at sea impose the need for having the means ' $[. .$.$] of ex-$ ercising the surveillance and defence of the Brazilian jurisdictional waters, as well as the maintenance of the security of the sea lines of communications' (Ministry of Defence of Brazil 2005: Strategic Orientations, 6.14). For that purpose, the National Defence Policy (NDP) states that Brazil must 'intensify the cooperative exchanges with the friendly nations' armed forces, particularly those in South America and Africa, bordering the South Atlantic (Ministry of Defence of Brazil 2005: topic 7.1, xx). About the operational perimeter established by the NDP, the following passage proves enlightening:

The defence planning includes all regions and in particular the vital areas where there is greater concentration of political and economic power. Complementarily, it prioritises the Amazon and the South Atlantic due to the wealth of resources and vulnerability of access by land and sea borders (Ministry of Defence of Brazil 2005: topic 4.3).

And: 'The sea has always been associated with the progress of Brazil, since the discovery of the country. Brazilian natural maritime vocation is backed by its extensive coastline and by the strategic importance represented by the South Atlantic' (Ministry of Defence of Brazil 2005: topic 4.5).

In the same line of argumentation, we can notice that the idea for the expansion of Brazil's areas of strategic interest (or strategic surroundings) emerged in the Brazilian National Defence Policy of 2005 (Fiori 2013: 32; Mattos 2014). The South Atlantic is regarded in that document as an area where Brazil seeks to expand its influence and diplomatic, economic, and military leadership. According to this document: 'The country views its strategic surroundings as going beyond the subcontinent and including the projection of the South Atlantic border and the coastal countries of Africa' (Ministry of Defence of Brazil 2005: topic 3.1).

Moreover, the 2012 National Defence Policy makes the definition of these areas even clearer: 'South America is the regional environment in which Brazil is inserted. As it seeks to deepen its co-operation links, the country sees strategic surroundings that go beyond the South American region and include the South Atlantic and the coastal countries of Africa, as well as Antarctica' (Ministry of Defence of Brazil 2012b: 21).

Finally, we should mention that the interest in the Antarctica, stated in the 2012 document, also dates back to the 1970s and has been related to the strategic concern with the South Atlantic. In 1975, Brazil acceded to the 1959 Antarctic Treaty, which keeps countries from testing weapons and exploiting natural resources in the area, and became an Advisory member with voting rights as of September 1983. The Institute for Brazilian 
Antarctic Studies was created in 1972. Then, in 1982, the first scientific expedition was launched and the Brazilian Antarctic Program was created, having been coordinated by the Brazilian Navy since then. This area is seen as strategically important because of the commercial routes that pass through the strait of Drake and the Cape route and because of its environmental impact (Mattos 2014).

The strategic interest in the Antarctica also justifies the investment in nuclear propelled submarines. According to Leonardo Faria de Mattos, the threat lies in the possibility of disrespect of the Antarctic Treaty, and nuclear submarines have a role to play in deterrence in this respect, particularly in the parts of the continent of interest to Brazil, i.e. those facing the South Atlantic (Mattos 2014: 186). In other words, the concern with the Antarctica is closely connected with the concern with the South Atlantic.

In sum, the framing of the South Atlantic as a strategic area is a fundamental feature of the justification for the nuclear propelled submarine put forward by the Brazilian ruling elites. Another important aspect of that refers to how the security logic framing the South Atlantic is conceived by those elites in terms of a specific deterrence rationality. The next section explores that latter aspect further.

\section{Framing security and the deterrence argument}

As we mentioned in the introduction to this article, in the sphere of development and international autonomy one can find frames that also allow us to understand the Brazilian choice to build a nuclear-propelled submarine. Nevertheless, herein we chose to analyse how the arguments about threats in the South Atlantic, mentioned in the previous section, and arguments on deterrence constitute a security framing, which, in turn, helps us to understand how the nuclear-propelled submarine is made possible.

In a nutshell, the nuclear submarine has been regarded by the Brazilian ruling elites as a tool for strategic flexibility and superior surveillance and access, helping secure Brazil's security interests, including the control of natural resources in the South Atlantic and the denial of access to outside actors. As we quoted in the previous section, the 2005 NDP establishes a link between the Brazilian interest in the sea and the need for having the means '[...] of exercising the surveillance and defence of the Brazilian jurisdictional waters, as well as the maintenance of the security of the sea lines of communications'; it also points out the need for intensifying 'the cooperative exchanges with the friendly nations' armed forces, particularly those in South America and Africa, bordering the South Atlantic.'

Given this growing interest in the South Atlantic and the stated need to improve the resources available for operations in this theatre, the nuclear submarine was gradually consolidated in the domestic political debate as the most viable means for the protection of the Brazilian interests at sea.

High-ranking members of the Navy often justify the efforts for the development and construction of a nuclear submarine by mentioning the natural resources present in Brazilian waters and the consequent need to protect these resources. For example, in September 2008, during the activation of the General Coordination Unit of the Nuclear Submarine Development Program (Coordenadoria-Geral do Programa de Desenvolvimento do 
Submarino Nuclear, COGESN), Admiral of the Fleet Marcus Vinicius Oliveira dos Santos, the general director of the Equipment of the Navy at the time, held:

The vastness of the South Atlantic and the magnitude of the Brazilian interests in the sea, among other considerations, led the Navy, many years ago, to decide to equip the Brazilian naval power with nuclear submarines. It then began the development of a nuclear programme, designed to enable the country to master the nuclear fuel cycle and to build a prototype reactor capable of meeting the needs of a nuclear-powered plant for the submarine (Admiral Oliveira dos Santos, quoted in Submarino Nuclear 2008).

The military establishment has been producing specialised knowledge in the field of strategic analysis and defence studies that frame the strategy related to the management of the South Atlantic area. Arguments of threat associated with arguments for the need to carry out a deterrence strategy have justified investment in the nuclear submarine.

Since the initial phases of the nuclear submarine project, the argument for the development of this equipment is inscribed in the logic of threat definition in the South Atlantic. The presence of the United Kingdom in the South Atlantic during the Malvinas/ Falklands war of 1982 and the support they received from the United States, de facto making the Rio Treaty null, boosted the perception of the deterrence need in the South Atlantic. The logic of deterrence is thus a crucial argument in the framing of the strategy of the Brazilian Navy.

In academic terms, deterrence is generally defined as a strategy which aims at manipulating the behaviour of others through conditional threats. The literature has come up with various terms to make sense of the different ways to employ this strategy. First of all, two differentiations are common: 'deterrence by punishment' and 'deterrence by denial'. The former means that an actor B will be deterred in its action due to the threat of retaliation made by A. The latter involves the denial of an easy victory to an actor B, who ends up being deterred by the high costs imposed by $\mathrm{A}$ in response to a possible attack perpetrated by B (Freedman 2005).

In deterrence by denial, the objective is to originate a scenario in which a certain course of action ceases to be a viable choice. Deterrence by denial comprises the threat to control the situation to the point that there would be almost no choice from the part of the deterred, since he/she would have diminished prospects of success and would end up deciding not to attack (Freedman 2005). In contrast, deterrence by punishment does not deprive the deterred from the capability to choose, but incentives are conferred to her/him so that she/he chooses a particular direction. The prospect of punishment, for example (present in the case of deterrence by punishment) increases the costs of an action, potentially causing a hostile force to give up an attack. These incentives derive from the certainty of retaliation under the same terms of the attack and/or of the destruction of targets valuable by the opponent (Freedman 2005).

The deterrence arguments presented by the Brazilian Navy authorities come closer to the aforementioned strategy of 'deterrence by denial'. The nuclear submarine is supposed 
to deny an easy victory to a possible enemy by raising the costs of acting against Brazilian interests in the South Atlantic.

The official argument begins by stating that, given the wealth present in the South Atlantic and the possibility of exploitation of such wealth by external actors, the nuclear submarine should serve as a deterrence or conflict-prevention strategy. In the naval authorities' own words:

The greatness of our coastline, where recent oil reserves that a few years ago would be considered unimaginable were found, demands a responsible and dutiful posture, so that the resources that the Blue Amazon contains in its depths are explored on behalf of the Brazilian people, for this and future generations. Thus, the submarine with nuclear propulsion in our fleet means the assumption of a serious commitment to a society that craves for a Navy with real deterrent power, and who deposits, on this same Navy, the confidence to see safeguarded the natural resources which are essential for the economic and social development of the country (Admiral Oliveira dos Santos, quoted in Submarino Nuclear 2008: 9; authors' emphasis).

In addition, the nuclear submarine is stated as serving a general defensive posture, a tradition of Brazilian strategic thinking which was confirmed in the document that formalised the defence policy of Brazil in 2005, the National Defence Policy (NDP). Interestingly, the NDP establishes a relationship between defence and deterrence: 'The preventive approach of the National Defence lies in the appreciation of the diplomatic activity as the primary instrument of conflict resolution and in a strategic posture based on the existence of a credible military capability, able to generate a deterrent effect' (Ministry of Defence of Brazil 2005: topic 6.2).

In the same sense, the National Defence Strategy (NDS, Estratégia Nacional de Defesa) of 2008, which seeks to operationalise the posture established in the 2005 document, starts from the following major guideline that involves: 'Deterring the concentration of hostile forces at land borders, at the limits of the Brazilian jurisdictional waters, and to avoid the use of national airspace' (Ministry of Defence of Brazil 2008: 11). And completes that: 'In order to deter, one must be prepared to fight. The technology, however advanced it may be, will never be an alternative to combat. It will always be an instrument of combat' (Ministry of Defence of Brazil 2008: 11). The official argument is that good defence capabilities are a means to deter eventual attacks.

About the performance of deterrence at sea, the NDS states that:

The priority is to ensure the means to deny the use of the sea to any concentration of enemy forces approaching Brazil by sea. The denial of the use of the sea to the enemy is what organises, before attending any other strategic objectives, the Brazilian strategy for maritime defence (Ministry of Defence of Brazil 2008: 20). 
The objective of denying the use of the sea to the opponent (at the expense of sea control and power projection) influences the composition of the Brazilian maritime forces and the planned strategies and tactics of war. Accordingly, the NDS states:

The constitution of a force and a naval strategy incorporating the submarine, surface and air components will enhance the flexibility with which the overriding goal of the maritime security strategy is protected: deterrence by denial of the use of the sea to the enemy approaching Brazil from the sea. In a broad spectrum of circumstances of combat, especially when the enemy forces are much more powerful, the surface force will be designed and operated as a tactical or strategic reserve. Preferably, and whenever the tactical situation permits, the surface force will be engaged in the conflict after the initial employment of the submarine force, that will act in coordination with space capabilities (for purposes of monitoring) and air power (for focused fire) (Ministry of Defence of Brazil 2008: 22).

It is important to observe, therefore, that the documents that formalise the Brazilian policy and the defence strategy attach great emphasis to submarines, since they would be responsible for the beginning of combat; only later, and if needed, would the surface fleet be used. There is, accordingly, an expectation that the very possibility that Brazil would undertake this first phase of submarine warfare has enough deterrent potential to prevent potential adversaries from threatening Brazilian interests in the South Atlantic. This expectation helps give meaning to Brazilian efforts to possess submarines with large displacement capacity and autonomy.

In defining our general naval strategy, officials have also argued that conventional submarines should not be ruled out: conventional submarines should be used in coastal areas and in limited patrol areas, while nuclear submarines should be used for the defence of more distant maritime frontiers, due to their greater mobility and longer submersion time (Moura Neto 2013).

The insertion of the nuclear submarine within a system of defence capable of deterring potential threats to the South Atlantic given the existence of oil resources located 110 kilometres out in the Atlantic Ocean is also proposed by three leading scholars in the debate on Brazilian national defence, Oliveira, Cepik, and Brites (2014). They suggest a military operation concept integrating three layers of defence (interior lines, coastal defence, and forward defence) that should be devised. This system should be able to avoid the threat of a war on two fronts, from the interior and from the sea, which would make the defence of oil platforms in the South Atlantic almost impossible, paralysing the country in strategic terms. They do not mention any imminent threat, but point out that in several regions oil import dependency is seen as a problem. The third layer of defence is composed of, among others items, nuclear-propelled submarines. As they are faster, they can remain submerged for longer periods and have greater autonomy so they are considered crucial for the country's defence system. The development of military bases on the islands of Fernando de Noronha and Trindade and Martin Vaz is also mentioned. 
When it comes to the identification of threats, the Brazilian deterrence strategy is peculiar for not being directed against specific targets. The National Defence Strategy does not clearly name potential enemies that might be the targets of deterrence. Thus we may understand the Brazilian position in terms of a strategy known in the academic field as a 'general deterrence strategy'. General deterrence often does not have a specific target, making use of generic and non-targeted threats which aim to prevent the military adventurism of external powers (Gerson and Whiteneck 2009: 48). For the success of this strategy, the continuous demonstration of power is needed, and this is often achieved through joint military exercises with a large plurality of actors and the deployment of troops abroad. Over time, general deterrence can be internalised by the deterred actor, and a challenge by the deterred party on the resolve of the one who deters becomes less likely.

In contrast to the logic of immediate deterrence (when an enemy is clearly identified), general deterrence presupposes that A seeks to influence the behaviour of the opponent when she/he establishes her/his defence policy, even if neither party is planning an attack. The objective is to prevent other actors from even thinking about an attack (Freedman 2005). Thus, in general deterrence, targets are not always clear, the strategy often being directed to any potential aggressor.

On the other hand, another way to academically qualify the Brazilian deterrence strategy is by referring to the concept of 'conventional deterrence'. Conventional deterrence, by which A threatens to attack B with non-nuclear devices if he/she undertakes an unwanted course of action, is based on the premise that potential adversaries will attack if they expect to have a quick and quite inexpensive victory. As occurs with the logic of deterrence by denial, the strategy of conventional deterrence often attempts to deny the enemy the opportunity to win a quick and inexpensive war (Gerson and Whiteneck 2009; Gerson 2009). The success of the conventional deterrence strategy depends, therefore, on convincing a potential adversary that he/she cannot quickly win any war started by him/ her. According to Mearsheimer: '[...] deterrence is best served when the attacker believes that his only alternative is a protracted war: The threat of a war of attrition is the bedrock of conventional deterrence' (cited in Gerson 2009: 37). This is due to the fact that long wars are harmful to the economy and create domestic instability for governments. In other words, conventional deterrence is often used to respond to the possible use of a fait accompli strategy, that is, a strategy which comprehends a surprise attack to rapidly occupy a territory and, shortly thereafter, the reversion to a defensive position (from the point of view of strategy) in order to protect the newly occupied territory.

In the same vein as the official declarations and strategic documents mentioned above, during the seminars held from 2013 to 2015 in the course of the academic project from which the present article stems, Brazilian Naval authorities have stressed that deterrence is the wisest strategy for the country, since it increases the costs of a foreign attack against Brazilian interests. According to naval authorities interviewed, a nuclear submarine is a crucial way of deterring potential threats, as it increases the costs of attacking Brazilian assets. More specifically, Navy authorities have insisted that a nuclear submarine deters an easy victory to any other powers. 
In sum, the Brazilian deterrence strategy can be interpreted through the concepts of 'general deterrence', 'conventional deterrence', and 'deterrence by denial'. If potential enemies are identified at all, it is done in the 2012 White Paper in which extra-regional nuclear powers are expected not to interfere in the South Atlantic area: 'Their military presence [of nuclear powers] on that ocean should be reduced, and eventually eliminated. Conflicts and rivalries foreign to the South Atlantic should not be projected onto it by states located in other regions' (Ministry of Defence of Brazil 2012a: 36).

Thus, it is possible to analyse the framing of the nuclear-propelled submarine project in terms of deterrence as embedded in a broader argument about threats. The South Atlantic has become a referent object, and the debate on the subject involves a definition of the nature of the threat and on how much political priority it deserves.

\section{Concluding remarks}

In this text, we have focused on the arguments put forward by the Brazilian ruling elites which frame the nuclear propelled submarine as a necessary response to potential threats in the South Atlantic Ocean. This was made possible by two interconnected frames. On the one hand, the South Atlantic has been framed as a strategic area related to security and development issues, justifying the investment in the submarine project, which is one of the main features of the Brazilian nuclear policy. On the other hand, deterrence has been characterised, especially by the Navy, as the best strategy to deal with this area.

After presenting an overview of the state of the submarine project in the first section, raising its main characteristics and obstacles, the second section dealt with the framing of the South Atlantic. We argued that the ruling elites frame it as a strategic area that is potentially under threat and that agglutinates the interests of a number of countries. Arguments referring to potential co-operative partners as well as potential threats are mobilised in the framing process of that area. In this sense, certain African and Latin American countries become important partners to Brazilian efforts of co-operation. Moreover, the concern with the Antarctica also plays a part in how the ruling elites conceive the strategic dimension of the South Atlantic.

Drawing on a brief discussion about the notions of 'conventional deterrence', 'deterrence by denial', and 'general deterrence', the third section sought to analyse the notion of deterrence which is framed by Brazilian ruling elites as a necessary response to deal with the South Atlantic area. We contend that the Brazilian strategy can be understood in terms of a general and conventional deterrence strategy, that is, when no specific targets are clearly stipulated and no nuclear weapons are used. In addition, Brazilian authorities argue that the submarines deny potential enemies the possibility of an easy victory against Brazil, and this is the very characteristic of deterrence by denial.

The understanding of the nuclear-propelled submarine project is not restricted to the study of how it is conceived by the ruling elites. But the discussion herein developed states that this framing process is a crucial dimension of Brazilian nuclear policy. In addition, it is also important to note that this framing has been received with resistance by various 
agents in both the domestic and the international spheres. However, by focusing on the ruling elites' frames, this text attempted to specify a crucial part of the political process involved in a project that is a hub of concerns related to national development and national autonomy, as well as budget disputes, co-operative initiatives, and security concerns.

\section{Notes}

1 We discuss the other two elsewhere (Herz, Dawood and Lage, forthcoming).

2 The US and the United Kingdom use highly enriched uranium (HEU), that is, uranium enriched to more than $90 \%$, in their submarines. In turn, Russia uses uranium enriched to more than $20 \%$ and France is believed to use low-enriched uranium (LEU). Accordingly, although the use of LEU in submarines is possible, nuclear weapon states fear that Brazil may choose uranium enriched to more than 20\% (Kassenova 2014).

3 This information was provided by National Commission on Nuclear Energy (CNEN) members and Brazilian diplomats during the workshop Brazilian Nuclear Policy, held at the BRICS Policy Center, Rio de Janeiro, from 9 to 10 May 2013.

4 The ruling elite refer to those in control of strategic decision-making processes in society. The ruling elite changes constantly and includes actors that have access to economic, military, political, and cultural resources that allow for a significant impact in the way a given society is governed. The competition between various regional or functional elites, clearly present during the democratic phase of Brazilian history, will not be analysed although it has core relevance to the debate developed here. See Albertoni (1987).

5 The Brazilian Submarine programme, as well as the whole Brazilian nuclear policy programme, is today threatened by the arrest under corruption charges of Admiral Othon and other authorities involved in the nuclear sector, and by the demise of Odebrecht, the main contractor for the programme (Saigg 2016).

6 Information available at: http://www.naval.com.br/blog/2012/07/06/marinha-do-brasil-inicia-projeto-dosubmarino-de-propulsao-nuclear/. Accessed on 20 March 2017.

$7 \quad$ The contract with France establishes the nationalisation of technology by both the Navy and the private sector. The Ministry of Defence has stated its commitment to guarantee the continuation of this process. For more information, see Ministry of Defence of Brazil (2015).

8 Information available at: http://www.adesg.net.br/noticias/o-programa-de-reaparelhamento-da-marinha. Accessed on 20 March 2017.

9 The data we present in this paragraph was taken from the information on the budget of the Ministry of Defence, which can be accessed at: http://www.defesa.gov.br/orcamento. We also rely on the graph presented by the Ministry of Defence, available at: http://www.defesa.gov.br/arquivos/orcamento_financas/ despesas_2015.jpg. Accessed on 20 March 2017.

10 The information presented in this paragraph is available at: http://www.naval.com.br/blog/destaque/ peamb/11-os-principais-programas-da-marinha-do-brasil/. Accessed on 20 March 2017.

11 This information is available at: http://www.defesa.gov.br/arquivos/orcamento_financas/execucao_ orcamentaria_2000_2015.pdf. Accessed on 20 March 2017.

12 We should recall that the construction of the South Atlantic is but one of the main arguments at stake in the general framing process; the others, as we mentioned in the beginning of the text, relate to autonomy and development. These other aspects are developed elsewhere.

13 This is stated on the Navy's website, available at: https://www1.mar.mil.br/dhn/leplac. Accessed on 20 March 2017.

14 The UNGA endorsement of the ZOPACAS is available at: http://www.un.org/documents/ga/res/41/ a41r011.htm. Accessed on 20 March 2017.

15 This Declaration is available at: http://www.un.org/documents/ga/res/49/a49r026.htm. Accessed on 20 March 2017.

16 Information available at: http://www.defesa.gov.br/index.php/noticias/8406-parceria-brasil-e-africa-dosul-fortalecem-cooperacao-na-area-de-defesa. Accessed on 20 March 2017. 


\section{References}

Abdenur, Adriana Erthal and Danilo Marcondes de Souza Neto. 2013. 'Brazil in the South Atlantic: growing protagonism and unintended consequences.' NOREF. May 2013. At: http://www.peacebuilding.no/Themes/Norway-and-emerging-powers/Publications/Brazil-in-the-South-Atlanticgrowing-protagonism-and-unintended-consequences [accessed on 26 October 2013].

2014. 'Region-Building by Rising Powers: the South Atlantic and Indian Ocean rims compared.' Journal of the Indian Ocean Region 10(1): 1-17.

Acharya, Amitav. 2007. 'The Emerging Regional Architecture of World Politics', World Politics 59(4): 629-52.

2013. The Making of Southeast Asia: international relations of a region. Ithaca: Cornell University Press.

Achen, Christopher H and Duncan Snidal. 1989. 'Rational deterrence theory and comparative case studies.' World Politics 41(2): 143-69.

Albertoni, Ettori. 1987. Mosca and the Theory of Elitism. Oxford and New York: B. Blackwell.

Bigo, Didier. 2002. 'Security and Immigration: Toward a Critique of the Governmentality of Unease.' Alternatives 27 (Special Issue): 63-92.

Castro, Luis Augusto de Araújo. 1989. O Brasil e o Novo Direito: Mar territorial e zona econômica exclusiva. Brasília: FUNAG.

Castro, Ronaldo Fiuza. 2012. 'Programa esporão.' Revista Marítima Brasileira 132(07-09): 23-38.

Correa, Fernanda das Graças. 2012. 'Projeto do submarino nuclear brasileiro: ciência, tecnologia, cerceamento e soberania nacional'. Revista Marítima Brasileira 132(07-09): 11-5

2010. O projeto do submarino nuclear brasileiro. Uma história de ciência, tecnologia e soberania. $2^{\text {nd }}$ ed. Rio de Janeiro: Capax Dei.

Crawford, Neta C. 2002. Argument and Change in World Politics: Ethics, Decolonization, and Humanitarian Intervention. Cambridge: Cambridge University Press.

Diehl, Sarah and Eduardo Fujii. 2008. 'Brazil's pursuit of a nuclear submarine raises proliferation concerns.' WMD Insights, March 2008: 9-18, At: http://cns.miis.edu/wmd_insights/WMDInsights_2008_03.pdf. [accessed on 3 November 2013].

Fragelli, José Alberto Accioly. 2012. 'O primeiro submarino de propulsão nuclear brasileiro.' Revista Marítima Brasileira 132(07-09): 17-8.

Freedman, Lawrence. 2005. Deterrence. Cambridge: Polity Press.

Gerson, Michael. 2009. 'Conventional deterrence in the second nuclear age'. Parameters, Autumn 2009: 32-48. At: http://strategicstudiesinstitute.army.mil/pubs/.../gerson.pdf. [accessed on 31 October 2013].

Gerson, Michael and Daniel Whiteneck. 2009. 'Deterrence and influence: the Navy's role in preventing war.' CNA. March 2009. At: http://www.dtic.mil/cgi-bin/GetTRDoc?AD=ADA497123 [accessed on 31 October 2013].

Goffman, Irving. 1974. Frame Analysis An Essay on the Organization of Experience. New York: Harper \& Row.

Herz, Monica. 2014. 'Regional Governance.' In Thomas G Weiss and Rorden Wilkinson (eds), International Organization and Global Governance, $1^{\text {st }}$ ed. London / New York: Routledge, pp. 236-50. 
Herz, Monica, Layla Dawood and Victor Coutinho Lage. Forthcoming. Brazilian Nuclear Policy (book under review to be published in 2017).

Huysmans, Jef. 2006. The Politics of Insecurity: Fear, Migration and Asylum in the EU. London: Routledge.

Kassenova, Togzhan. 2014. Brazil's nuclear kaleidoscope: An evolving identity. Washington: Carnegie Endowment for Peace.

Krause, Keith. 1999. 'Rationality and deterrence in theory and practice'. In Craig Snyder (ed), Contemporary security and strategy. New York: Routledge, pp. 120-47.

Luis, Camila Cristina Ribeiro. 2013. 'Estratégia naval da Marinha: elemento direcionador ou vetor da ação externa brasileira no Atlântico Sul?’ SEBREEI. At: http://www.sebreei.eventos.dype.com. br/resources/anais/21/1365815734_ARQUIVO_CAMILA_SEBREEI.pdf [accessed on 31 October 2013].

2012. 'A estratégia naval brasileira no contexto da política exterior.' Revista da Escola de Guerra Naval 18(1): 153-72. At: https://www.egn.mar.mil.br/arquivos/revistaEgn/junho2012/ed icao18.155-174.pdf [accessed on 31 October 2013].

Martins Filho, João Roberto. 2011. 'O projeto do submarino nuclear brasileiro.' Contexto Internacional 33(2): 277-314.

2012. 'The Brazilian Submarine Project.' Paper presented at the Workshop Brazil and Global Nuclear Order, co-hosted by Carnegie Endowment for International Peace and Fundação Getulio Vargas (FGV), Rio de Janeiro, Brazil, 15 May 2012.

Mearsheimer, John. 1983. Conventional deterrence. Ithaca: Cornell University Press.

Ministry of Defence of Brazil. 1996. Política de Defesa Nacional. At: http://www.oas.org/csh/ spanish/doclibrdefBras.asp [accessed on 26 October 2013].

. 2005. Política de Defesa Nacional. At: http://www.planalto.gov.br/ccivil_03/_Ato20042006/2005/Decreto/D5484.htm [accessed on 26 October 2013].

2008. Estratégia Nacional de Defesa. At: http://www.planalto.gov.br/ccivil_03/_ato20072010/2008/Decreto/D6703.htm [accessed on 26 October 2013].

2012a. Livro Branco de Defesa Nacional. At: http://www.defesa.gov.br/arquivos/2012/ mes07/lbdn.pdf [accessed on 3 November 2013].

2012b. Política de Defesa Nacional e Estratégia de Nacional de Defesa. At: http://www.defesa. gov.br/arquivos/estado_e_defesa/END-PND_Optimized.pdf [accessed on 12 July 2016].

Moura Neto, Almirante Julio Soares. 2013. 'A importância da construção do submarino de propulsão nuclear brasileiro.' Defesa Aérea \& Naval. At: http://www.defesaaereanaval.com.br/a-importancia-da-construcao-do-submarino-de-propulsao-nuclear-brasileiro/ [accessed on 13 July 2016].

NATO. 2010. NATO 2020: Assured Security; Dynamic Engagement, At: http://www.nato.int/cps/en/ natolive/official_texts_63654.htm [accessed on 13 July 2016].

Navy of Brazil. 2011. PROSUB: programa de desenvolvimento de submarinos. At: http://www.mar. mil.br/menu_v/ccsm/temas_relevantes/prosub-completo.pdf [accessed on 3 November 2013].

Neumann, Iver. 1994. 'A Region Building Approach to Norther Europe.' Review of International Studies 20(1): 53-74.

1999. The "East" in European Identity Formation. Manchester: Manchester University Press. 
Oliveira, Lucas Kerr, Marco Cepik, and Pedro Vinícius Brites. 2014. 'O pré-sal e a segurança do Atlântico Sul: a defesa em camadas e o papel da integração sul-americana.' Revista da Escola de Guerra Naval 20(1): 139-64.

Prazeres, Leandro. 2015. 'Tocado por empresa da Lava Jato, projeto de submarinos está atrasado 2 anos.' UOL, March 03. At: http://noticias.uol.com.br/politica/ultimas-noticias/2015/03/30/tocadopor-empresa-da-lava-jato-projeto-de-submarinos-esta-atrasado-2-anos.htm [accessed on 13 July 2016].

Sá, Andréa de. 2015. 'Brazil's Nuclear Submarine Program.' The Nonproliferation Review 22(1): 3-25. Saigg, Mahomed. 2016. 'Lava Jato volta a prender ex-presidente da Eletronuclear no RJ.' G1, 6 July. At: http://g1.globo.com/rio-de-janeiro/noticia/2016/07/pf-cumpre-mandados-da-operacao-lavajato-no-rio-e-porto-alegre.html [accessed on 12 July 2016].

Silva, Alexandre Pereira da. 2013. 'O Novo Pleito Brasileiro no Mar: A Plataforma Continental Estendida e a Amazônia Azul.' Revista Brasileira de Política Internacional 56(1): 104-21.

Submarino Nuclear. 2008. Revista Marítima Brasileira 128(10/12): 8-12.

Taylor, Paul. 2009. 'Why does Brazil need a nuclear submarine?' Proceedings Magazine. U.S. Naval Institute 135(6/1): 276.

Thompson, Nathan and Robert Muggah. 2015. 'Amazônia Azul: Brasil confirma sua influência do outro lado do Atlântico.' Carta Maior, June 16. At: http://cartamaior.com.br/?/Editoria/Internacional/Amazonia-Azul-Brasil-confirma-sua-influencia-do-outro-lado-do-Atlantico/6/33745 [accessed on 12 July 2016].

United Nations. 1986. Declaration of a Zone of Peace and Co-operation in the South Atlantic. October 27. At: http://www.un.org/documents/ga/res/41/a41r011.htm [accessed on 13 July 2016].

1994. Zone of Peace and Cooperation of the South Atlantic. 2 December. At: http://

www.un.org/documents/ga/res/49/a49r026.htm [accessed on 13 July 2016].

Vidigal, Armando Amorim. 2006. Amazônia Azul o Mar que nos Pertence. Rio de Janeiro: Record.

Viveiros, Daniel Theberge de and Diego da Silva Cespes. 2013. 'Submarino nuclear: poder de dissuasão no mar. Revista Marítima Brasileira 133(07-09): 201-9.

\title{
Useful online resources
}

\author{
ADESG: \\ 1. http://www.adesg.net.br/noticias/o-programa-de-reaparelhamento-da-marinha. Accessed on 7 \\ July 2016. \\ Navy of Brazil: \\ 1. https://www1.mar.mil.br/dhn/leplac. Accessed on 7 July 2016. \\ Ministry of Defence of Brazil: \\ 1.http://www.defesa.gov.br/noticias/17621-programa-de-submarinos-deve-ser-plenamente- \\ cumprido-diz-aldo. Accessed on 7 July 2016. \\ 2.http://www.defesa.gov.br/arquivos/orcamento_financas/execucao_orcamentaria_2000_2015.pdf. \\ Accessed on 7 July 2016. \\ 3.http://www.defesa.gov.br/orcamento. Retrieved on 7 July 2016.
}


4.http://www.defesa.gov.br/arquivos/orcamento_financas/despesas_2015.jpg. Accessed on 7 July 2016.

5.http://www.defesa.gov.br/index.php/noticias/8406-parceria-brasil-e-africa-do-sul-fortalecemcooperacao-na-area-de-defesa. Accessed on 22 March 2014.

Poder Naval:

1.http://www.naval.com.br/blog/destaque/peamb/11-os-principais-programas-da-marinha-dobrasil/. Accessed on 7 July 2016.

2.http://www.naval.com.br/blog/2012/07/06/marinha-do-brasil-inicia-projeto-do-submarino-depropulsao-nuclear/. Accessed on 13 July 2016.

\section{Acknowledgements}

Our thanks are due to the organisations which provided support for this research project: CNPq, FAPERJ, and the Hewlett Foundation. We also thank Lucas Peres for his assistance in the research for this article.

\section{About the authors}

Mônica Herz is Associate Professor at the Catholic University of Rio de Janeiro Institute of International Relations and holds a PhD from the London School of Economics and Political Science. Apart from several articles and chapters on Latin American security, nuclear and regional governance, and Brazilian foreign policy, she has written three books: Organizações Internacionais: histórias e práticas (2004, co-authors Andréa Ribeiro Hoffman and Jana Tabak); Ecuador vs. Peru: Peacemaking Amid Rivalry (2002, co-author, João Pontes Nogueira); and OAS Global Governance Away From the Media (2010). From 2004 to 2008, she was Director of the International Relations Institute (IRI) at PUC-Rio.

Layla Dawood is Assistant Professor at the State University of Rio de Janeiro (UERJ) and the Executive Secretary of the Brazilian Association for International Relations (ABRI). She holds a BA in International Relations from the Pontifical Catholic University of Minas Gerais, a BA in Law from the Federal University of Minas Gerais, an MA in International Relations from the Pontifical Catholic University of Minas Gerais, and a PhD in International Relations from the Pontifical Catholic University of Rio de Janeiro. Her research interests include International Relations Theory and International Security, with a focus on balancing Chinese and American defence policies, nuclear policy, and nonproliferation.

Victor Coutinho Lage is Sessional Lecturer of the Institute of International Relations (IRI) at PUC-Rio, and of the CPDOC at the Getúlio Vargas Foundation (FGV-Rio). He holds a $\mathrm{PhD}$ and a Master's degree in International Relations, both from IRI/PUC-Rio. Former visiting PhD student at the University of Victoria, Canada, he has published articles in important journals such as Revista Brasileira de Politica Internacional, Contexto Internacional, Carta Internacional, and The Nonproliferation Review. His PhD dissertation, Interpretations of Brazil, Contemporary (De)Formations, discusses the concept of 'formation' 
in the interpretations of Brazil of the twentieth century. His main research topics include contemporary philosophy, political theory and philosophy, (meta)theories of International Relations, interpretations of Brazil, and modernity and modernisation in Brazil.

Received on 15 July 2016 and approved for publication on 6 September 2016.

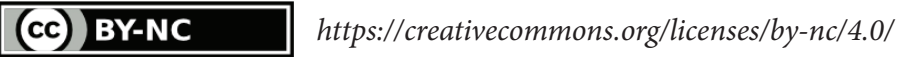

